\title{
Antiaging Potential of Peptides from Underused Marine Bioresources
}

\author{
Enqin Xia, Xuan Zhu, Xuebin Gao, Jindong Ni * and Honghui Guo *
}

check for updates

Citation: Xia, E.; Zhu, X.; Gao, X.; Ni, J.; Guo, H. Antiaging Potential of Peptides from Underused Marine Bioresources. Mar. Drugs 2021, 19, 513. https://doi.org/10.3390/ md19090513

Academic Editors: Hideki Kishimura, Yuya Kumagai and Marialuisa Menna

Received: 31 July 2021

Accepted: 7 September 2021

Published: 10 September 2021

Publisher's Note: MDPI stays neutral with regard to jurisdictional claims in published maps and institutional affiliations.

Copyright: (c) 2021 by the authors. Licensee MDPI, Basel, Switzerland. This article is an open access article distributed under the terms and conditions of the Creative Commons Attribution (CC BY) license (https:// creativecommons.org/licenses/by/ $4.0 /)$.
Dongguan Key Laboratory of Environmental Medicine, School of Public Health, Guangdong Medical University, Dongguan 523808, China; xiaenqin@gdmu.edu.cn (E.X.); zxuu1109@gdmu.edu.cn (X.Z.);

Gaoxueb@gdmu.edu.cn (X.G.)

* Correspondence: nijd-gw@gdmu.edu.cn (J.N.); guohh1999@gdmu.edu.cn (H.G.); Tel.: +86-769-2289-6569 (J.N.); +86-769-2289-6572 (H.G.)

\begin{abstract}
Aging is a biological process that occurs under normal conditions and in several chronic degenerative diseases. Bioactive natural peptides have been shown to improve the effects of aging in cell and animal models and in clinical trials. However, few reports delve into the enormous diversity of peptides from marine organisms. This review provides recent information on the antiaging potential of bioactive peptides from underused marine resources, including examples that scavenge free radicals in vitro, inhibit cell apoptosis, prolong the lifespan of fruit flies and Caenorhabditis elegans, suppress aging in mice, and exert protective roles in aging humans. The underlying molecular mechanisms involved, such as upregulation of oxidase activity, inhibition of cell apoptosis and MMP-1 expression, restoring mitochondrial function, and regulating intestinal homeostasis, are also summarized. This work will help highlight the antiaging potential of peptides from underused marine organisms which could be used as antiaging foods and cosmetic ingredients in the near future.
\end{abstract}

Keywords: antiaging; underused marine organism; peptides; mechanism

\section{Introduction}

In recent history, human life expectancy has continuously risen, and the proportion of the elderly population has sharply increased with the improvement of medical technology. Dysfunction of normal biological processes accompanies aging, and the acceleration of molecular damage and dysfunction in cells, tissues, and organs eventually leads to aging-related diseases, such as cardiovascular diseases, nutritional metabolic diseases, and cognitive disorders [1,2]. However, the aging process is adjustable, albeit irreversible, and scientific approaches can regulate the speed of aging and promote good health [3]. Therefore, development of efficient strategies to manage aging is critical for community health. In recent years, a growing body of work has aimed to test several hypotheses related to the molecular mechanisms that play critical roles in determining longevity. Among them, reactive oxygen species (ROS) inducing oxidative stress is considered one of the primary contributors to aging [4]. Hence, exploration of substances with antioxidant activity is an important strategy for the management of aging [5,6]. Many kinds of anti-aging drugs have been synthesized and tested in clinical trials, but many obstacles prevent drug development, including the adverse reactions of the human body to synthesized drugs. Therefore, natural active substances with high efficiency and low side effects are important alternatives for combating aging [6].

Recently, natural bioactive peptides have attracted special attention. Biologically active peptides with anticancer, anticoagulant, antidiabetic, antihypertensive, antimicrobial, antioxidant, and cholesterol-lowering properties have been reported in the biomedicine and pharmaceutical biotechnology literature [7]. Some of these compounds also exhibit notable antiaging activity in vitro or in vivo. Presently, potential bioactive peptides are mainly isolated and identified in different food products like milk, soy, rice, meat, fish, 
lobsters, crabs, and shrimp [8]. Some bioactive peptides are extremely safe, easily absorbed, and have no toxic side effects $[9,10]$. Moreover, because of their hypo-allergenicity characteristics, bioactive peptides have been explored as a method to treat patients with food allergies [11]. Therefore, bioactive peptides should be considered as excellent alternatives for anti-aging treatment.

Marine organisms contain high-quality functional protein or peptides with diverse molecular structures, and are an important source of new compounds, especially for China with its $18,000 \mathrm{~km}$ coastline, compared to terrestrial resources [12]. Presently, excluding various fish that are widely used as food materials, there is only limited use of marine protein resources from other species, such as sea cucumber, sea urchin, mussels, and several kinds of algae. Some marine bioactive peptides regulate free radical homeostasis in vitro and in vivo, and can have antiaging effects in cell and animal models and in human clinical trials [13-16]. Marine natural bioactive peptides have also been used in cosmeceutical skin products as antiaging agents [17-19].

In present work, we used the keywords "peptide" and "anti-aging" or "anti-aging", we searched the relevant literature published from 1956 to 10 July 2021 from several databases including PubMed, Cochrane Library, Web of Science and Embase. The resultant studies were screened for relevance to underused marine bioresources. Then, we comprehensively reviewed recent studies on antiaging activities of peptides from marine organisms, including their beneficial effects on the regulation of oxidative stress in vitro or in cells, fruit flies, nematodes, mice, and humans. In addition, we summarize the molecular mechanism underlying the antiaging activities of marine peptides. Overall, we aim to highlight useful information for furthering the use of marine sources for bioactive compounds.

\section{Antiaging Activity of Peptides from the Ocean}

Based on the limited literature, marine antiaging peptides have been shown to act in several different ways, including scavenging free radical capacities in vitro, inhibiting cell apoptosis, prolonging the life span of fruit flies and nematodes, and ameliorating D-galactose levels that induce aging in mice, and have shown promise as antiaging agents in human clinical trials.

\subsection{Free Radical Scavenging Activity and Sequence Characteristics of Peptides}

ROS are highly reactive agents in vivo and ROS homeostasis is a key factor in aging. Scavenging free radicals in vitro is a common underlying mechanism among antiaging agents. Therefore, we looked into peptides with free radical scavenging activity in vitro from underused marine resources and reported their $50 \%$ effective concentration $\left(\mathrm{EC}_{50}\right)$ values to provide support for their antiaging potential.

Free Radical Scavenging Activity

ROS are highly reactive substances, and overproduction of ROS can result in DNA mutation, lipid, and protein dysfunction, and, ultimately, aging [20]. Thus, the main protective strategy to slow aging is to scavenge the excessive ROS by providing antioxidant agents, as well restoring the antioxidant defense system in cells. In the human body, the antioxidant defense system consists mainly of antioxidant peptides, including carnosine, glutathione, and antioxidant enzymes, including superoxide dismutase (SOD), glutathione oxidase (GHS-Px) and catalase (CAT). Therefore, free radical scavenging activity in vitro can reveal potential antiaging activity. Many studies have reported free radical scavenging activity in vitro of marine peptides, and the data are provided in Table 1.

As shown in Table 1, we compiled a list of peptides with antioxidant capacity from several kinds of underused marine organisms, including microalgae and bacteria, several invertebrates, and byproducts of the fishing industry including the head, bone, skin, cartilage, viscera, and gelatin of various fish. In vitro assays show that these peptides scavenge several kinds of free radicals, including superoxide anion $\left(\mathrm{O}_{2}{ }^{-}\right)$, peroxide, hydroxyl radical $(\mathrm{OH})$ and 2,2-diphenyl-1-picrylhydrazyl (DPPH) radical, and can affect lipid peroxidation. 
Evidence for ferric reducing antioxidant power (FRAP, reducing $\mathrm{Fe}^{3+}$ to $\mathrm{Fe}^{2+}$ ) is lacking. Short chains with fewer than eight amino acids have been documented as effective antioxidant peptides. According to previous reports, smaller molecular weight peptides are suitable for more easily accessing the reaction center, and preferable for reacting with free radicals to stop the oxidation reaction chain [21]. Peptides with smaller molecular weight also easily penetrate the gastrointestinal barrier to exert their biological effects. In addition, the antioxidant capacity of some peptides from marine organisms can even reach or exceed that of vitamin $\mathrm{E}$ and quercetin. For example, the 50\% effective concentration $\left(\mathrm{EC}_{50}\right)$ of $\alpha$-Tocopherol is $0.52 \pm 0.03 \mathrm{mM}(0.246 \pm 0.014 \mathrm{mg} / \mathrm{mL})$ [22]. In comparison, all peptides from microorganisms, invertebrates and tissues of various fish have high antioxidant potential with $\mathrm{EC}_{50}$ values of about $1 \mathrm{mg} / \mathrm{mL}$, with no differences between the values in the muscle, skin, and head of fish. These values are about 5-10-fold lower than the $\mathrm{EC}_{50}$ value of the cartilage of the red stingray (Dasyatis akajei) fish, which performs superoxide anion radical scavenging with an $\mathrm{EC}_{50}$ in the range of $0.08-0.16 \mathrm{mg} / \mathrm{mL}$ [23]. In addition, for black pomfret (Parastromateus niger), peptides from the viscera exhibit stronger free radical scavenging activity than those from the whole body [24]. These results indicate that use of seafood industry by-products and other underused species may be an untapped source of antiaging peptides.

Table 1. Marine antiaging peptides and their free radical scavenging activity in vitro.

\begin{tabular}{|c|c|c|c|}
\hline Source & Sequences & Activities $\left(\mathrm{EC}_{50}\right)$ & Ref. \\
\hline \multicolumn{4}{|l|}{ Microorganism } \\
\hline Chlorella vulgaris & favourzyme hydrolysates & $\begin{array}{l}\text { Superoxide }^{3}(0.323 \mathrm{mg} / \mathrm{mL}) \\
\text { Hydroxyl }^{2}(0.139 \mathrm{mg} / \mathrm{mL})\end{array}$ & [25] \\
\hline Spirulina sp. & $\begin{array}{l}\text { Thr-Met-Glu-Pro-Gly-Lys-Pro } \\
\text { Ile-Leu-Thr-Lys-Ala-Ala-Ile-Glu-Gly-Lys }\end{array}$ & Inhibition of ROS production & [26] \\
\hline Dunaliella salina & $\begin{array}{l}\text { Ile-Ile-Tyr-Phe-Gln-Gly-Lys } \\
\text { Asn-Asp-Pro-Ser-Thr-Val-Lys } \\
\text { Thr-Val-Arg-Pro-Pro-Gln-Arg } \\
\text { N-cinnamoyl tripeptide }\end{array}$ & $\mathrm{DPPH}^{1}$ & [27] \\
\hline Penicillium brevicompactum & & $\begin{array}{l}\text { Hydroxyl }^{2} \text { (equivalent to that of quercetin at } \\
0.1 \mathrm{mM} \text { ) }\end{array}$ & [28] \\
\hline $\begin{array}{l}\text { Kocuria marina } \\
\text { Marine invertebrates }\end{array}$ & Phe-Glu, Asp-Ile, Ser-Ser-Gln, Leu-Glu & $\mathrm{DPPH}^{1}(0.24 \mathrm{mg} / \mathrm{mL})$ & [29] \\
\hline \multirow[t]{2}{*}{ Neptunea arthritica cumingii } & $\begin{array}{l}\text { Tyr-Ser-Gln-Leu-Glu-Asn-Glu-Phe-Asp-Arg } \\
\text { Tyr-Ile-Ala-Glu-Asp-Ala-Glu-Arg }\end{array}$ & $\begin{array}{l}\mathrm{DPPH}^{1}(0.77 \mathrm{mM}) \\
\mathrm{DPPH}^{1}(1.04 \mathrm{mM})\end{array}$ & [30] \\
\hline & Glu-Met-Gly-Pro-Ala & $\begin{array}{c}\mathrm{DPPH}^{1}(0.53 \pm 0.02 \mathrm{mg} / \mathrm{mL}), \text { Hydroxyl }^{2} \\
(0.47 \pm 0.03 \mathrm{mg} / \mathrm{mL}), \text { Superoxide }^{3} \\
(0.75 \pm 0.04 \mathrm{mg} / \mathrm{mL}), \\
\text { ABTS }^{4}(0.96 \pm 0.08 \mathrm{mg} / \mathrm{mL}), \text { Inhibition of lipid }\end{array}$ & \multirow[b]{2}{*}{ [31] } \\
\hline \multirow[b]{2}{*}{ Brachionus rotundiformis } & Trp-Pro-Pro-Asp & $\begin{array}{c}\text { peroxidation } \\
\mathrm{DPPH}^{1}(0.36 \pm 0.02 \mathrm{mg} / \mathrm{mL}), \text { Hydroxyl }^{1} \\
(0.38 \pm 0.04 \mathrm{mg} / \mathrm{mL}), \text { Superoxide }^{3} \\
(0.46 \pm 0.05 \mathrm{mg} / \mathrm{mL}), \text { ABTS }^{4} \\
(0.54 \pm 0.03 \mathrm{mg} / \mathrm{mL}), \text { Inhibition of lipid } \\
\text { peroxidation }\end{array}$ & \\
\hline & $\begin{array}{l}\text { Leu-Leu-Gly-Pro-Gly-Leu-Thr-Asn-His-Ala, } \\
\text { Asp-Leu-Gly-Leu-Gly-Leu-Pro-Gly-Ala-His }\end{array}$ & $\begin{array}{l}\operatorname{DPPH}^{1}(189.8 \mu \mathrm{M}) \\
\operatorname{DPPH}^{1}(167.7 \mu \mathrm{M})\end{array}$ & [32] \\
\hline Fish & & & \\
\hline \multirow{4}{*}{ Muscle of Scomberomorous niphonius } & Pro-Glu-Leu-Asp-Trp & $\begin{array}{l}\mathrm{DPPH}^{1}(1.53 \mathrm{mg} / \mathrm{mL}), \text { Hydroxyl }^{2}(1.12 \mathrm{mg} / \mathrm{mL}), \\
\text { Superoxide }^{2}(0.85 \mathrm{mg} / \mathrm{mL}) \text {, Inhibition of lipid } \\
\text { peroxidation, Protection of plasmid DNA }\end{array}$ & \multirow{4}{*}{ [33] } \\
\hline & Trp-Pro-Asp-His-Trp & $\begin{array}{l}\mathrm{DPPH}^{1}(0.70 \mathrm{mg} / \mathrm{mL}) . \text { Hydroxyl } \\
\text { Superoxide }^{3}(0.48 \mathrm{mg} / \mathrm{mg} / \mathrm{mL}) . \text { Inhibition of lipid } \\
\text { peroxidation, Protect plasmid DNA. }\end{array}$ & \\
\hline & Phe-Gly-Tyr-Asp-Trp-Trp & $\begin{array}{c}\mathrm{DPPH}^{1}(0.53 \mathrm{mg} / \mathrm{mL}), \text { Hydroxyl }^{2}(0.26 \mathrm{mg} / \mathrm{mL}) \\
\text { Superoxide }^{3}(0.34 \mathrm{mg} / \mathrm{mL}) \text {. Inhibition of lipid } \\
\text { peroxidation, }\end{array}$ & \\
\hline & Tyr-Leu-His-Phe-Trp & $\begin{array}{c}\mathrm{DPPH}^{1}(0.97 \mathrm{mg} / \mathrm{mL}), \mathrm{Hydroxyl}^{2}(0.67 \mathrm{mg} / \mathrm{mL}) \\
\text { Superoxide }^{3}(1.37 \mathrm{mg} / \mathrm{mL}), \text { Inhibit lipid } \\
\text { peroxidation. }\end{array}$ & \\
\hline
\end{tabular}


Table 1. Cont.

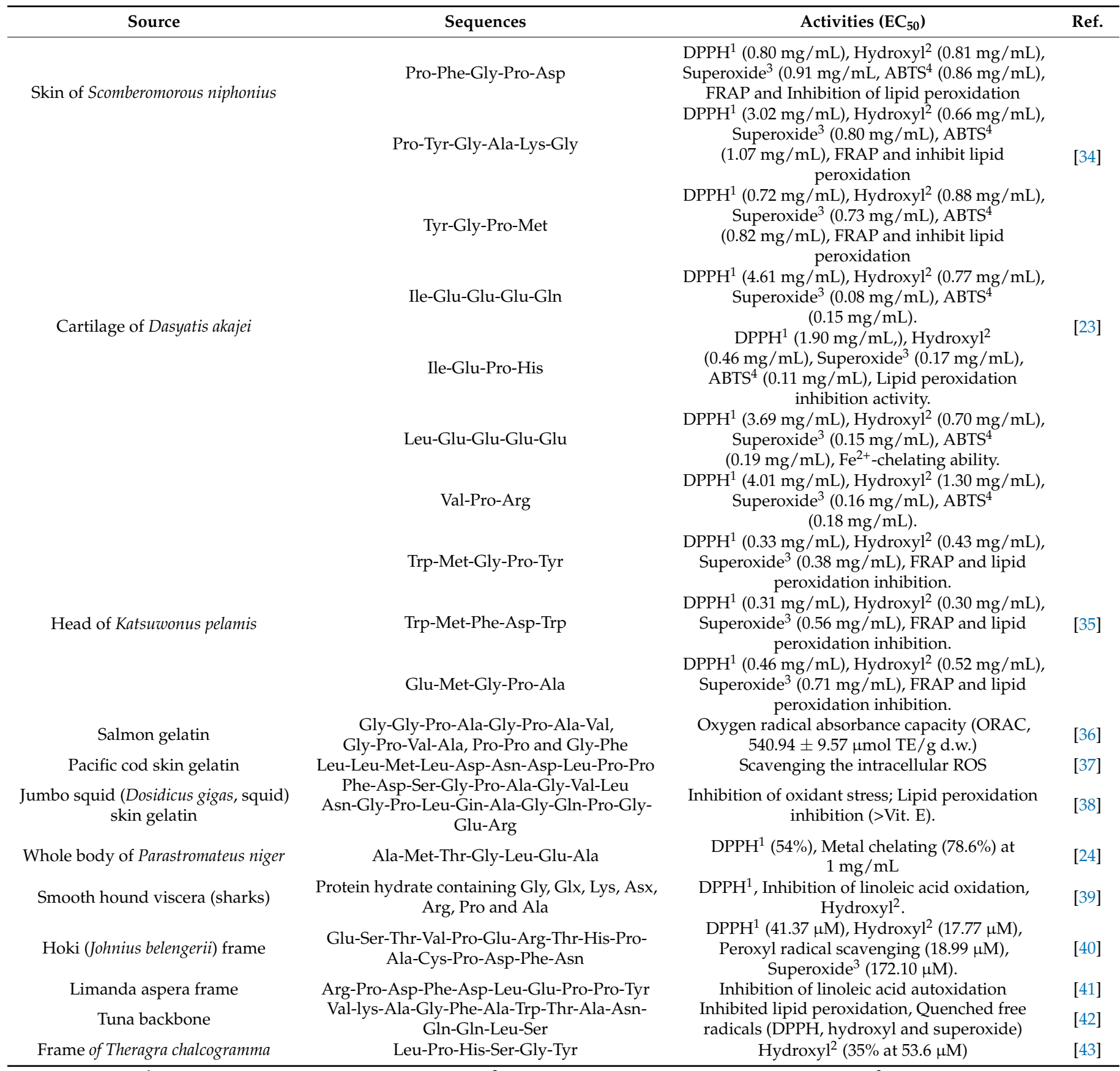

Note: DPPH ${ }^{1}$-DPPH radical scavenging capacity, Hydroxyl2 ${ }^{2}$-Hydroxyl radical scavenging capacity, Superoxide ${ }^{3}$-Superoxide anion radical scavenging capacity, $\mathrm{ABTS}^{4}-\mathrm{ABTS}$ cation radical scavenging capacity.

\subsection{Inhibition of Cell Apoptosis}

In cell assays, peptides from marine organisms can protect cells injured by ROS induced by several external stimuli, including $\mathrm{H}_{2} \mathrm{O}_{2}$, ethanol, UV-irradiation, and wounding. Cells used in these assays include human umbilical vein endothelial cells (HUVECs), human hepatocellular carcinomas (HepG2), human skin fibroblasts, and human immortalized keratinocytes ( $\mathrm{HaCaT})$.

$\mathrm{H}_{2} \mathrm{O}_{2}$ is usually used as an oxidative stress inducer due to its presence in cells and role in redox metabolism. When HUVECs suffer from $\mathrm{H}_{2} \mathrm{O}_{2}$, excessive ROS are generated and deplete intracellular antioxidant enzymes, resulting in apoptosis [44-46]. Recently, Oh and coworkers (2021) investigated two cytoprotective peptides, His-Gly-Ser-His and 
Lys-Gly-Pro-Ser-Trp, derived from seahorse (Hippocampus abdominalis). At $600 \mu \mathrm{M}$ of $\mathrm{H}_{2} \mathrm{O}_{2}$ treatment, high-level intracellular ROS in HUVECs can be detected [47] and apoptotic and necrotic cells are observed [48]. In addition, the cell survival rate of the experimental group decreased by $65.43 \%$. After pretreatment with $100 \mu \mathrm{g} / \mathrm{mL}$ of these two peptides alone or in combination, HUVECs viability was restored to $81.02 \%, 78.55 \%$ and $80.05 \%$ for His-Gly-Ser-His, Lys-Gly-Pro-Ser-Trp, and a 1:1 combination of the two, respectively. Surprisingly, the two peptides were not found to exhibit DPPH radical scavenging activity in vitro, suggesting that there are other avenues by which the two peptides counteract oxidative stress induced by $\mathrm{H}_{2} \mathrm{O}_{2}$ in cells [47].

Ethanol is another ROS inducer that acts by increasing cytochrome P450 enzyme 1 (CYP2E1) levels, resulting in oxidative stress and hepatotoxicity in alcohol consumers. The effect of marine peptides from the hydrolysate of the microalgae Navicula incerta protein on ethanol-injured HepG2/CYP2E1 cells has been investigated. Cells were pretreated for $1 \mathrm{~h}$ with two peptides, Pro-Gly-Trp-Asn-Gln-Trp-Phe-Leu and Val-Glu-Val-Leu-ProPro-Ala-Glu-Leu, at a series of concentrations $(0-100 \mu \mathrm{M})$ and then treated with $1.0 \mathrm{M}$ ethanol for $48 \mathrm{~h}$. No toxic effect was observed in cells treated with the two peptides at a concentration of $100 \mathrm{mM}$. The strongest rescue of cell viability by pretreatment with the two peptides was almost 30\%. Significant inhibition of gamma-glutamyltransferase (GGT) activity, an indicator of cytotoxicity, was observed. Similarly, both peptides caused concentration-dependent increases in GSH activity. Across all metrics, Pro-Gly-Trp-AsnGln-Trp-Phe-Leu outperformed Val-Glu-Val-Leu-Pro-Pro-Ala-Glu-Leu [49]. Thus, these two marine bioactive peptides successfully suppress oxidative stress caused by ethanol.

Ultraviolet (UV) irradiation is a very efficient ROS inducer, especially in human skin, where ROS levels can rise dramatically after only 15-min of UV exposure [50]. There is evidence that marine peptides from fish collagen can partly counteract UV-damage. Human skin fibroblasts pretreated with $0.125 \%, 0.25 \%$ or $0.5 \%$ fish collagen for $24 \mathrm{~h}$ were UV-irradiated $\left(10 \mathrm{~J} / \mathrm{cm}^{2}\right)$ for $24 \mathrm{~h}$, and cell viability was restored by $7.9 \%, 22.3 \%$ and $28.1 \%$, respectively. Moreover, mitochondrial activity was restored by $30.6 \%, 16.4 \%$ and $36.1 \%$, respectively [51]. In another cell assay carried out by Han and coworkers, UV irradiation decreased the survival rate of HaCaT cells, illustrated by a total apoptosis rate of $66.8 \pm 1.27 \%$. However, after treating injured HaCaT cells with Ile-Cys-Arg-Asp and Leu-Cys-Gly-Glu-Cys, two peptides isolated from Tuna roe by enzymatic hydrolysis, the apoptosis rate significantly decreased and the levels of SOD and GSH-Px increased significantly to more than 60 and $45 \mathrm{U} / \mathrm{mL}$, respectively. Levels of MDA decreased by more than $11 \mathrm{nmol} / \mathrm{mL}$ compared to the control group [52].

Wound-recovery activities involve migration and proliferation of keratinocytes, which are essential for tissue healing. In a scratch-assay wounding model in HaCaT cells, $1 \mu \mathrm{g} / \mathrm{mL}$ of PEP, an antioxidant peptide from fermented Trapa Japonica fruit, significantly promotes wound healing: a 4.4-fold increase in the recovery of the scratched area was observed in PEP-treated cells. These studies also found that marine peptides can boost wound-recovery by increasing migration and proliferation of keratinocytes [53,54].

\subsection{Prolonging Lifespan in Model Organisms}

Several researchers have reported that marine peptides have the potential to prolong lifespan in Caenorhabditis elegans and fruit fly. The fruit fly is frequently employed as an aging model because its genus purity is very high and its lifespan is very short [55]. In addition, it behaves analogously to mammalian hepatocytes in terms of lipid metabolism and transport systems [56]. Moreover, its lifespan is closely associated with oxidative stress, and lipid peroxidation of membranes results in injury of tissues and organs, which might play key roles in the aging process [57]. Aside from studying normal aging, researchers can also induce early aging in the fruit fly by administering D-galactose [55,58]. The effect of peptides from marine sources on simulated aging of the fruit fly has been investigated by Lin and coworkers [59]. Two peptide fractions with MW below $3000 \mathrm{Da}$ from Stichopus variegates (SVH-PF) were administered at final concentrations of 1, 4 and 
$8 \mathrm{~g} / \mathrm{L}$. The intervention culture medium fed to fruit flies contained peptide fractions and $40 \mathrm{~g} / \mathrm{L}$ D-galactose. Compared to the normal controls, SVH-PF/SVH-CAH-PF (4 and $8 \mathrm{~g} / \mathrm{L}$ ) increased the maximum lifespan of fruit flies by $12.3 \% / 11.4 \%$ and $24.8 \% / 23.8 \%$, respectively. The increases were $18.1 \% / 24.0 \%$ and $21.0 \% / 24.3 \%$ compared to the negative control group. These data prove that there is a detectable positive effect of marine peptides on lifespan in D-galactose-induced aging in the fruit fly [59]

Caenorhabditis elegans is attractive model organism for antiaging research, and the effects of marine peptides on its lifespan have also been reported. Sonani et al. administered a dietary supplement with purified phycoerythrin (PE) to normal Caenorhabditis elegans to assess its anti-aging potential. PE $(100 \mu \mathrm{g} / \mathrm{mL})$ treatment increased the mean life-span of Caenorhabditis elegans from $15 \pm 0.1$ to $19.9 \pm 0.3$ days. Degeneration of physiological functions was also moderated by PE treatment. In addition, PE treatment can raise tolerance to thermal and oxidative stress from $22.2 \pm 2.5$ to $41.6 \pm 2.5 \%$ and $30.1 \pm 3.2$ to $63.1 \pm 6.4 \%$, respectively, for 5-day-old adults. Excitingly, PE treatment can also affect the levels of a peptide linked to muscle paralysis in an Alzheimer's disease model [60].

According to $\mathrm{Yu}$ et al., total enzymatic hydrolysate and both $<3 \mathrm{kDa}$ and $>3 \mathrm{kDa}$ hydrolysate fractions from Sepia esculenta exhibit significant dose-dependent protective effects in Caenorhabditis elegans individuals treated by $50 \mathrm{mM}$ of paraquat at concentrations in the range $0.5-4.0 \mathrm{mg} / \mathrm{mL}$. Two peptides, Asp-Val-Glu-Asp-Leu-Glu-Ala-Gly-Leu-Ala-Lys and Glu-Ile-Thr-Ser-Leu-Ala-Pro-Ser-Thr-Met, obtained from Sepia esculenta also exhibit notable antioxidant capacity in Caenorhabditis elegans by increasing SOD activity and decreasing the levels of ROS and malondialdehyde (MDA) in paraquat-treated nematodes [61]. Similarly, three novel antioxidant peptides, Leu-Ser-ASp-Arg-Leu-GLu-Glu-Thr-Gly-Gly-Ala-Ser-Ser, Lys-Glu-Gly-Cys-Arg-Glu-Glu-Pro-Glu-Thr-Glu-Lys-Gly-His-Arg, and Ile-Val-Thr-AsnTrp-Asn-Asn-Met-Glu-Lys, from Meretrix meretrix can also rescue paraquat-induced damage in nematodes [62]. Moreover, the favourzyme hydrolysates of Chlorella vulgaris protein, which have antioxidant activity, can significantly prolong lifespan, decrease ROS levels, and increase the activity of antioxidant enzymes such as CAT and SOD in Caenorhabditis elegans [23].

Aside from toxic substances, excessive glucose intake has also been shown to disturb energy homeostasis and result in the accumulation of fat in Caenorhabditis elegans, which promotes the generation of ROS and even induces lipid peroxidation and oxidationdamage [63]. After pretreatment with two peptides, Asp-Val-Glu-Asp-Leu-Glu-Ala-GlyLeu-Ala-Lys and Glu-Ile-Thr-Ser-Leu-Ala-Pro-Ser-Thr-Met, obtained from Sepia esculenta, the levels of fat accumulation and lipid peroxidation induced by $10 \mathrm{mM}$ glucose were significantly decreased, while ROS and MDA levels were restored [61]. In addition, Herring milt protein hydrolysates can also improve glucose homeostasis in obese mice fed a high-fat $\operatorname{diet}[64]$.

\subsection{Ameliorating D-Galactose Induced Aging in Mice}

In antiaging studies, mouse models of aging can be induced by D-galactose [65]. During induction, D-galactose causes accumulation of ROS and an increase in oxidative stress and damage to cell membrane lipids [66]. The earliest damage is found in the liver. Then, a series of pathogenesis linked to aging and metabolic syndrome are observed in succession. Therefore, metabolic disorder and oxidant stress are considered the two key factors for aging. To make matters worse, disorders of glucose and lipid metabolism can lead to susceptibility of cells and tissues to oxidative stress.

Zhu et al. showed that after treatment with D-galactose $(200 \mathrm{mg} / \mathrm{kg})$, mice age and exhibit more missing hair and whiskers, obvious kyphosis, and abdominal obesity, and significantly higher mean senescence scores compared with control mice. Mice treated with mussel peptides have more hair and bushy whiskers, as well as lower body weight and liver indexes, improvements to disorders of glucose and lipid metabolism, increased antioxidant capacity, and slowed aging [67]. 


\subsection{Antiaging Effects in Human Clinical Assays}

Peptides obtained by hydrolysis, isolation and purification from fish and other food material exhibit antiaging potential. Recently, in a randomized crossover intervention study, a lean-seafood diet was found to impact mitochondrial energy metabolism of healthy human subjects based on detection of urinary markers. In the study, the intervention group ate a diet with several lean fish, including cod, pollack, saithe and scallops, and the control group ate a diet of land protein including chicken, lean beef, turkey, pork, egg, milk and milk products. Twenty healthy human subjects out of 148 subjects completed the 8 weeks test. Results showed that the lean-seafood intervention significantly decreased the levels of carnitine, an acylcarnitine and N1-methyl-2-266 pyridone-5-carboxamide (2PY) in urinary samples, indicating that mitochondrial function was improved [68]. The data suggest that for healthy subjects, a lean seafood diet of cod, pollack, saithe, and scallops might increase antioxidative capacity of mitochondria, boost normal lipid catabolism, and lower oxidative stress [68]. Clinical studies examining diets containing potential anti-aging peptides from marine fish bioresources and peptides from underused species are an important avenue for further study.

Apart from oral administration assays, studies on skin aging using cosmetics with marine peptides have also been carried out [69]. In terms of underused marine sources, PEP, a synthesized peptide based on the structure of the antioxidant polypeptide from Trapa japonica fruit extract, has been recently evaluated at the clinical trial level for antiaging effects on skin. The intervention employs an eye cream at $0.5 \%$ concentration. Results showed that $0.5 \%$ PEP intervention for eight weeks resulted in significantly less skin wrinkling [64].

Collagen synthesis is considered a key factor in skin aging [53,70]. Sufficient amino acids and oligopeptides binding to the surface of fibroblasts are both important for collagen synthesis [71]. Therefore, oral supplementation of low molecular weight hydrolyzed collagen $(0.3-8 \mathrm{kDa})$ can prevent aging by providing ample material for collagen synthesis by human skin fibroblasts. The results indicate that small molecular weight peptides from collagen support collagen synthesis and improve the structure of extracellular matrix (ECM). In line with this, several studies have reported that small peptides from hydrolyzed collagen can stimulate the formation of ECM proteins, boost fibroblast proliferation, and slow aging after UV-irradiation and other harmful external environmental stimuli $[14,16,72]$.

\section{The Mechanisms Underlying Antiaging Activity}

Marine peptides that exhibit free radical scavenging activity in vitro (Table 1) have potential antiaging effects. However, other mechanisms may also be involved in slowing aging in vivo, including an increase in the activity of antioxidant enzymes, regulation of Klotho, inhibition of apoptosis, inhibition of matrix metalloproteins-1 (MMPs-1) expression, protection of mitochondrial activity by correct protein folding and decreased DNA mutation by the chaperonin containing t-complex polypeptide 1 and the phosphatase and tensin homolog (CCT-PTEN) Pathway, restoration of intestinal homeostasis and regulation of aging-related metabolic disorders.

\subsection{Improvement of Antioxidant Enzyme Activity}

Antioxidant enzymes are an important target of peptides in cells and organisms. The underlying mechanisms involved include regulation of the classical antioxidant gene Klotho and the Keap1/nuclear fac-tor erythroid 2-related factor 2- antioxidant responsive element (Nrf2-ARE) signaling pathway. In addition, marine peptides can regulate DAF16/FOXO-SOD-3 expression, i.e., a forkhead transcription factor/forkhead transcription factors of the $\mathrm{O}$ class, which can enhance antioxidant enzyme activity.

\subsubsection{Regulation of Keap1/Nrf2-ARE Expression}

Nrf2, a multidomain repressor protein inhibited by binding to Keap 1, is an essential transcription factor that regulates the expression of an array of detoxifying and antioxidant 
defense genes. Nrf2 and Keap1 are co-expressed in many organs. Upon stimulation by ROS, for example after UV irradiation or exposure to $\mathrm{H}_{2} \mathrm{O}_{2}, \mathrm{Nrf2}$ is released from Keap1 and activated. Free Nrf2 can enter the cell nucleus and combine with antioxidant response elements (AREs). Then, the complex boosts the transcriptional activity of antioxidant enzymes. Simultaneously, the transcription levels of Keap1 and Nrf2 are increased. The Keap1/Nrf2-ARE pathway, as an important antioxidant pathway, plays a significant role in regulating the levels and activities of antioxidant enzymes such as GSH-Px and SOD [73]. Natural peptides from marine sources have been found to protect cells from damage by targeting this pathway.

Two peptides obtained from Tuna roe, Ile-Cys-Arg-Asp and Leu-Cys-Gly-Glu-Cys, have strong DPPH radical scavenging activity in vitro and lead to significant rescue of $\mathrm{HaCaT}$ cell exposed to ultraviolet B (UVB) radiation [52]. Further, transcription of antioxidation-related genes, such as Keap1, Maf, CAT, glutathione S-transferases (GST), and $\mathrm{Mn}-\mathrm{SOD}$ are restored to normal levels, while the transcription of $\mathrm{Nrf2}, \mathrm{Cu}-\mathrm{SOD}$, and GSH-Px increases to significantly higher levels than those in the model group, with stronger effects observed for the Leu-Cys-Gly-Glu-Cys peptide. Thus, these two peptides protect $\mathrm{HaCaT}$ cells irradiated by UV via this classical redox pathway [52].

The antiaging properties of the Leu-Cys-Gly-Glu-Cys peptide have been verified in healthy mouse models. After treatment with the peptides, mice display a healthier status based on a series of body indices, such as increased body weight and decreased liver and brain indices. Based on the analysis of liver and serum samples, the peptide was found to increase the activity of serum GSH-Px and SOD and decrease levels of MDA. Additionally, the transcription levels of Keap1 and Nrf2 were significantly downregulated in the liver and brain. These results confirmed that marine bioactive peptides can be used as potential regulators of aging in cells and mice, extending the earlier findings that showed it can scavenge free radicals in vitro. These results also highlight the importance of the Keap1/Nrf2-ARE pathway in antiaging [52].

Using immunofluorescence assays, Cai and coworkers showed that after treating $\mathrm{H}_{2} \mathrm{O}_{2}$-injured HUVECs with the Phe-Pro-Tyr-Leu-Arg-His peptide from the swim bladder of the miiuy croaker (Miichthys miiuy), Nrf2 translocation and accumulation in the nucleus are both down-regulated. In addition, expression of heme oxygenase isozyme-1 (HO-1) increases significantly. These data indicate that Nrf2 nuclear translocation induces HO-1 overexpression, thus preventing apoptosis of $\mathrm{H}_{2} \mathrm{O}_{2}$-injuried HUVECs [74].

\subsubsection{Regulation of Klotho}

Klotho, known as an aging gene in mammals, regulates several molecular processes including phosphate homeostasis, insulin signaling, and Wnt signaling [75,76]. Moreover, tumour suppressor p53/p21, cyclic adenosine monophosphate (cAMP), and protein kinase $\mathrm{C}(\mathrm{PKC})$ are influenced by Klotho. Klotho deficiency leads to susceptibility to several aging-relative diseases and vasculogenesis [77-79]. Thus, regulation of Klotho expression is an important strategy for antiaging studies.

A Stichopus variegates peptide fraction, $\mathrm{SVH}-\mathrm{PF} / \mathrm{SVH}-\mathrm{CAH}-\mathrm{PF}$, contains a considerable number of small peptides with MW below $3000 \mathrm{Da}$ [59]. A series of changes are observed in the liver, brain, and serum of mice exposed to D-galactose at a daily dose of $100 \mathrm{mg} / \mathrm{kg}$, as well as a decrease in the activities of SOD and GSH-Px and an increase in MDA and protein carbonyl levels. Combining D-galactose treatment with orally administered SVH-PFS and SVH-CAH-PF at doses of 200, 500 or $1000 \mathrm{mg} / \mathrm{kg}$ for eight consecutive weeks enhances the activities of SOD and GSH-Px in the liver and brain of aging mice, suggesting that the deterioration induced by D-galactose is prevented. In addition, MDA levels decreased (vs. negative control) by over $50 \%$ in the liver and $23 \%$ in the brain after treatment with SVH-PFS/SVH-CAH-PF at $1000 \mathrm{mg} / \mathrm{kg}$. At a dose of $1000 \mathrm{mg} / \mathrm{kg}$, SVHPF/SVHCAH-PF administration inhibited the formation of protein carbonyls in the liver, brain, and serum sufficiently to keep them at normal levels. Furthermore, pretreatment with both SVH-PF and SVH-CAH-PF at doses of 500 and $1000 \mathrm{mg} / \mathrm{kg}$ efficiently increased 
Klotho expression in brain [59]. Simultaneously, the peptide fractions effectively promoted longevity and attenuated oxidative injury in D-galactose-treated fruit flies by boosting Klotho expression [59].

\subsubsection{Regulation of DAF-16/FOXO SOD-3 Expression}

DAF-16, a forkhead transcription factor, is a Caenorhabditis elegans orthologue to the mammalian FOXO proteins which regulates stress resistance and longevity $[80,81]$. The effects of three Meretrix meretrix antioxidant peptides, Leu-Ser-ASp-Arg-Leu-GLuGlu-Thr-Gly-Gly-Ala-Ser-Ser, Lys-Glu-Gly-Cys-Arg-Glu-Glu-Pro-Glu-Thr-Glu-Lys-GlyHis-Arg and Ile-Val-Thr-Asn-Trp-Asn-Asn-Met-Glu-Lys, on the expression of the relevant genes has been investigated. First, in the transgenic Caenorhabditis elegans strain GR1352 in normal conditions, $4.0 \mathrm{mM}$ of peptides can significantly increase DAF-16: green fluorescent protein (GFP) localization to cell nuclei. Next, when the transgenic Caenorhabditis elegans strain CF1553 expressing a SOD-3: GFP reporter was treated by $4.0 \mathrm{mM}$ of three peptides, the level of SOD-3 significantly increased. Further investigation showed that the sod-3 transcript level increased more than two-fold, and the ctl- 1 and ctl-2 transcript levels also increased about two-fold after treatment with the Leu-Ser-ASp-Arg-Leu-GLu-GluThr-Gly-Gly-Ala-Ser-Ser peptide. Meretrix meretrix peptides enable nematodes to resist oxidative stress induced by paraquat via up-regulation of DAF-16 [62]. In addition, two antioxidant peptides, Ala-Ala-Val-Pro-Ser-Gly-Ala-Ser-Thr-Gly-Ile-Tyr-Glu-Ala-Leu-GluLeu-Arg and Asn-Pro-Leu-Leu-Glu-Ala-Phe-Gly-Asn-Ala-Lys, from Strongylocentrotus nudus, also enhance nuclear translocation of DAF-16 and the expression sod-3 in nematodes damaged by oxidant stress [82].

The mechanisms of action of two antioxidant peptides, Asp-Val-Glu-Asp-Leu-Glu-AlaGly-Leu-Ala-Lys and Glu-Ile-Thr-Ser-Leu-Ala-Pro-Ser-Thr-Met from Sepia esculenta, that promote survival of Caenorhabditis elegans treated with paraquat have also been investigated. Transgenic CF1553 nematodes expressing sod-3p:GFP were used [61]. After the nematodes were treated with the two peptides, expression of the antioxidant enzyme genes, sod-3 and cat-1, were significantly increased from baseline levels. Further, the authors showed that these marine peptides protected oxidation-damaged worms via the p53 signaling pathway and sod-3 and cat-1 [61]. However, dietary supplementation with phycoerythrin (PE, $100 \mu \mathrm{g} / \mathrm{mL}$ ) extends lifespan in mutant Caenorhabditis elegans with knock-out of upstream (daf-2 and age-1) and downstream (daf-16) regulators of insulin/IGF-1 signaling (IIS). These results show that PE does not act through the DAF-2-AGE-1-DAF-16 signaling pathway [60]. More work is required to uncover the underlying mechanisms in this case.

\subsection{Inhibition of the Autophagy and Apoptosis}

As summarized in Table 1, marine antioxidant peptides have potential as antiaging agents because they can protect cells from oxidative stress by directly scavenging excess free radicals. In addition, marine peptides can inhibit apoptosis via two pathways: the p53Bax/Bcl-2 (BCL2-associated X protein/B lymphoblastic cells) pathway and the Mammalian target of rapamycin complex 1 (mTORC1)-mTOR-Bcl/Bax pathway.

\subsubsection{Directly Scavenging Excess Free Radicals}

Mitochondria are an important producer of ROS. Its ROS production pathways include the electron transport chain, xanthine oxidase pathway, phospholipase activated arachidonic acid metabolism pathway, and arginine nitric oxide synthase pathway [83]. Under unhealthy conditions, the levels of ROS lose their dynamic balance, resulting in cell damage, cell aging, cell apoptosis, etc [84]. With strong oxidative activity, excessive ROS can lead to DNA fragmentation, damage to the integrity of the cell membrane, and damage to the structure and function proteins. Several studies have shown that high concentrations of ROS can initiate apoptosis. In addition, carcinogens such as aflatoxin $\mathrm{B} 1$, bisphenol A, and heterocyclic amine lead to an increase in intracellular ROS levels throughout the process of tumorigenesis [85]. The peptides listed in Table 1 could therefore 
inhibit apoptosis by protecting mitochondria. The mechanisms involved are displayed in Figure 1.

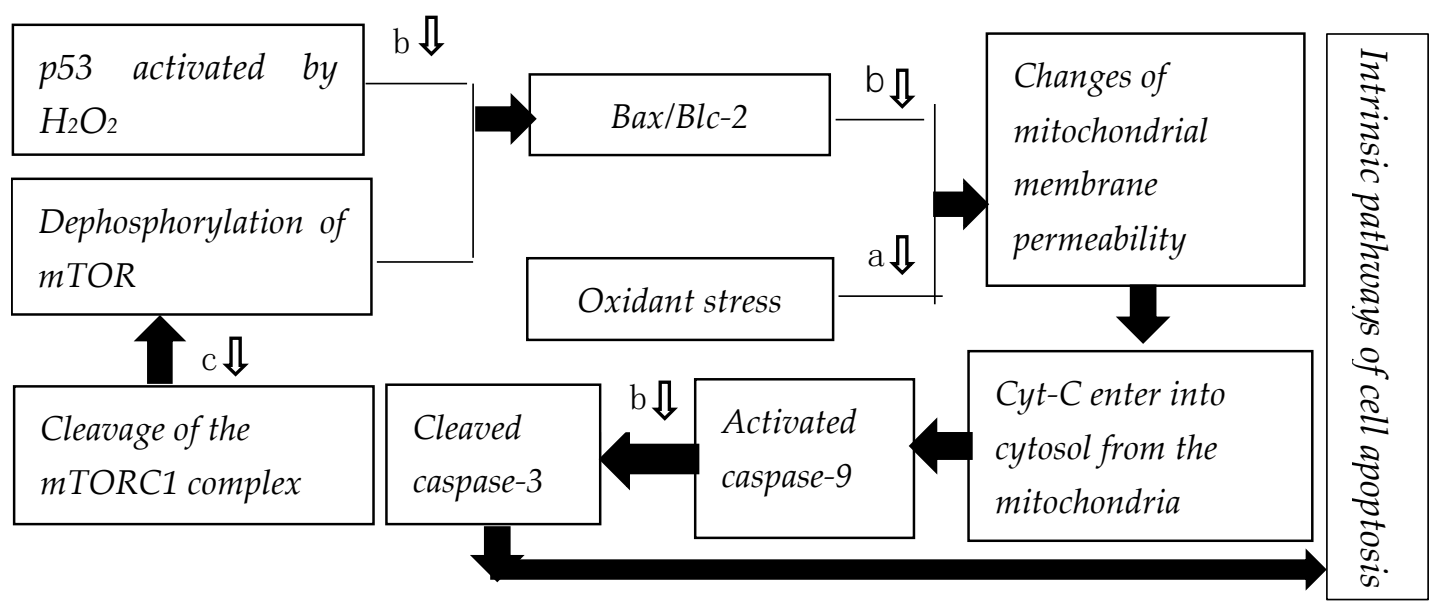

Figure 1. Marine peptides intervene in the intrinsic pathway of cell apoptosis (Note: a-scavenging free radical peptides in Table 1, b-Mytilus edulis hydrolysate, and c-peptide from Trapa japonica fruit).

\subsubsection{Regulation of p53-Bax/Bcl-2 Pathway}

Apoptosis involves morphological changes, such as cell shrinkage and chromatin condensation, and is regulated by several proteins including p53, caspase-3, and bcl-2 [48]. Mitochondrial DNA damage caused by oxidative stress can activate p53, which then executes the cell apoptosis program [86]. When p53 is activated by oxidative stress, there is an increase in bax expression and a decrease in bcl-2 expression, which increases the $\mathrm{Bax} / \mathrm{Bcl}-2$ ratio. The relative expression of $\mathrm{Bax}$ and $\mathrm{Bcl}-2$, a pair of proteins that promote and inhibit apoptosis, governs the mitochondrial release of cytochrome $\mathrm{C}(\mathrm{Cyt}-\mathrm{C})$ into the cytosol [48]. At the same time, oxidative stress induced by $\mathrm{H}_{2} \mathrm{O}_{2}$ increases the permeability of the mitochondrial membrane. These two factors synergistically enhance the release of Cyt-C into the cytosol. Caspase- 9 is activated by elevated Cyt-C concentration in the cytosol. Subsequently, caspase- 9 activates caspase-3 by cleavage. Finally, cleaved caspase-3 is activated, and the cell carries out apoptosis [87].

The levels of p53 and caspase- 3 and the Bax/Bcl-2 ratio induced by $\mathrm{H}_{2} \mathrm{O}_{2}$ decrease by $0.86-, 2.33$ - and 1.47-fold, respectively, when $\mathrm{H}_{2} \mathrm{O}_{2}$-treated HUVECs are treated with blue mussel (Mytilus edulis) hydrolysate (BMEH) at a concentration of $0.5 \mathrm{mg} / \mathrm{mL}$. BMEH significantly decreases $\mathrm{H}_{2} \mathrm{O}_{2}$-mediated apoptosis of HUVECs by decreasing the expression of p53 and caspase-3 genes and the Bax/Bcl-2 ratio (Figure 1) [45].

\subsubsection{Regulation of mTORC1-mTOR-Bcl/Bax Apoptosis Pathway}

mTOR is a serine/threonine kinase that is a part of the PI3K-related kinase family, an apoptosis activating group [88-90]. As raptor decreases, mTOR is released from the mTORC1 complex. Then, dephosphorylation of mTOR and oxidative stress lead to an increase in the $\mathrm{Bcl} / \mathrm{Bax}$ ratio $[90,91]$. According to Nam et al., dihydrotestosterone $(1 \mathrm{mg} / \mathrm{mL})$ can significantly decrease the levels of phosphorylated-mTOR and raptor in human dermal papilla cells, leading to increased dephosphorylation of mTOR, initiation of apoptosis, and autophagy of mitochondria and membranes. Treatment with the peptide from Trapa japonica fruit $(10 \mathrm{mg} / \mathrm{mL})$ inhibits cleavage of the mTORC1 complex and restores cell viability. These data suggest that marine peptides can inhibit cleavage of the mTORC1 complex, allowing them to suppress autophagy and apoptosis in injured human dermal papilla cells [92,93] (Figure 1). 


\subsection{Regulation of the TNF- $\alpha$-MMPs-ECM Pathway to Suppress MMP-1 Expression}

Imbalance of the ECM structure and dysfunction of fibroblasts cause the skin aging. Fibroblasts residing in the dermis just under epidermis build the ECM. ECM is mainly composed of collagens, among which type I collagen accounts for $80 \%$ of total collagen. Collagens are important for skin elasticity, flexibility, and tension, and are digested by matrix metalloproteinases (MMPs) [94,95]. MMP-1 (collagenase-1) is responsible for degeneration and inhibition of type I collagen synthesis $[96,97]$. Tumour necrosis factor-alpha $(\mathrm{TNF}-\alpha)$, a major inflammatory cytokine, activates MMP-1 and MMP-9 expression and inhibits collagen synthesis in human dermal fibroblasts (HDFs) [98].

Recently, Jang et al. treated HDFs with $1 \mu \mathrm{g} / \mathrm{mL}$ of PEP, a peptide synthesized based on the sequence of a peptide from fermented Trapa Japonica fruit, prior to treatment with $20 \mathrm{ng} / \mathrm{mL}$ of TNF- $\alpha$. PEP restored normal levels of MMP- 1 and MMP-9 induced by TNF- $\alpha$. In addition, collagen synthesis increased by $95 \%$ compared to controls [53].

\subsection{Regulation of CCT-PTEN Pathway to Protect Mitochondria}

Mitochondrial activity is essential for proper cell function. A decline of mitochondrial activity is associated with division, migration, and aging of cells, and accompanies the onset of several diseases. Very recently, multiple studies reported that several marine peptides can restore or improve mitochondrial function after damage by exposure to external stimuli such as $\mathrm{H}_{2} \mathrm{O}_{2}$ and UV-radiation $[45,47,99,100]$.

UV-irradiation of human skin fibroblasts results in cell division, migration, and apoptosis due to protein dysfunction by misfolding and mitochondrial DNA lesions. CCT, containing CCT1-CCT8 subunits, forms a chaperone complex with tailless complex polypeptide 1 (TCP1) to ensure correct protein folding [101]. PTEN-induced kinase 1 (PINK1)/Parkin-mediated mitophagy can counteract the effects of mitochondrial DNA mutation in flies [102]. After $24 \mathrm{~h} \mathrm{UV}$ treatment $\left(10 \mathrm{~J} / \mathrm{cm}^{2}\right)$, collagen peptides from the hydrolysis of fish collagen protein restore the expression levels of CCT2, CCT5, CCT6A, CCT8, and PINK1 genes to normal levels. The collagen peptides not only enhanced the expression of elastin and collagen and relieved the damage caused by ROS, but also boosted protein folding and DNA repair, lowering the risk of DNA mutation in UV-treated fibroblasts [51].

\subsection{Restoration of Intestinal Homeostasis and Regulation of Aging-Related Metabolic Disorders}

Gut microbiota, including both beneficial and harmful flora, is an important part of the human gastrointestinal tract. Beneficial microbiota can contribute to the health of the intestinal tract by ensuring complete absorption and utilization of the diet nutrients, synthesizing some nutrients and bioactive substances, consuming harmful substances, and controlling population levels of harmful bacteria, which can produce harmful metabolites and damage the health of the host $[103,104]$. Drosophila melanogaster models have shed some light on the animal-microbial symbiosis and can be used to test the impact of active compounds on the gut microbiome [105]. Based on the microbial differences between Drosophila melanogaster and other species, it appears that microbial content is independent of species consistency. It is, however, closely associated with diet, and similar diets lead to similar microbial composition even among different species [106,107]. Diet and metabolism, and not microbe species, influence the composition of gut microbiota. In addition, significant changes in intestinal microbiota are observed as severe age-related physiological diseases, especially metabolic diseases, develop, suggesting that age-related intestinal changes may seriously affect the overall health and lifespan of the host [107-109]. Studies have unveiled the mechanisms by which gut microbiota enhance antioxidant capacity in vivo $[110,111]$. For example, Lactobacillus has been shown to consume metal ions and prevent metal ion oxidation [112]. The gut microbiome is closely linked with host aging, and therefore, treatments that regulate the composition and metabolism of gut microbiota can improve health and slow aging. Data concerning the impact of antioxidant peptides derived from marine sources on gut microbiota are summarized in Table 2. 
Table 2. Regulation of gut microbiota by marine peptides.

\begin{tabular}{|c|c|c|c|}
\hline Marine Peptides & Test Animal & Improvement of Gut Microbiota & Ref. \\
\hline $\begin{array}{l}\text { Spirulina Phycocianin } \\
\text { (Microalgae) }\end{array}$ & Mice & $\begin{array}{l}\text { Increase the relative abundance of Bacteroidetes and } \\
\text { Actinobacteria }\end{array}$ & [113] \\
\hline Glycosylated fish protein & Mice & $\begin{array}{c}\text { Increase the abundance of Allobaculum, Akkermansia, } \\
\text { Lactobacillus animalis }\end{array}$ & [114] \\
\hline Walleye Pollock skin & Mice & $\begin{array}{l}\text { Upregulation relative abundance of Lactobacillus and } \\
\text { Akkermansia, downregulation the abundance of } \\
\text { bacteria associated with intestinal inflammation }\end{array}$ & [115] \\
\hline $\begin{array}{l}\text { Skin collagen peptide of Salmon } \\
\text { salar and Tilapia nilotica }\end{array}$ & Male rats & Increased abundance of Lactobacillus & [116] \\
\hline $\begin{array}{l}\text { Herring milt hydrolysate } \\
\quad \text { (protein: } 47-94 \% \text { ) }\end{array}$ & Mice & $\begin{array}{c}\text { Maintain abundant of Lactobacillus } \\
\text { decrease metabolites associated with obesity and } \\
\text { inflammatory disease }\end{array}$ & [117] \\
\hline Peptides from tuna roe & Mice & $\begin{array}{l}\text { Short-chain fatty acids production in feces and } \\
\text { modulating gut microbiota composition }\end{array}$ & [52] \\
\hline Abalone viscera & Alcohol induced injured mice & $\begin{array}{l}\text { Increase in diversity index and the number of Bacilli } \\
\text { (class), Lactobacillales (order), Lactobacillaceae (family), } \\
\text { and Lactobacillus (genus) levels }\end{array}$ & [118] \\
\hline $\begin{array}{l}\text { Spirulina platensis protease } \\
\text { hydrolyzate }\end{array}$ & High-fat diet (HFD)-fed rats & Enriched the abundance of gut beneficial bacteria & [119] \\
\hline $\begin{array}{l}\text { Chlorella pyrenoidosa protein } \\
\text { hydrolysate-calcium chelate }\end{array}$ & Low-calcium diet-fed rats & $\begin{array}{l}\text { Improving the abundances of Firmicutes and } \\
\text { Lactobacillus }\end{array}$ & [120] \\
\hline $\begin{array}{l}\text { Oyster polypeptide }(\mathrm{OP}) \\
\text { fraction }\end{array}$ & Exhaustive fatigue mice & $\begin{array}{l}\text { regulate the abundance of gut microbiota and } \\
\text { maintain its balance }\end{array}$ & [121] \\
\hline
\end{tabular}

As shown in Table 2, recent investigations have focused on the impact of marine peptides on gut microbiota. The test substances have included protein hydrolysates, polypeptide fractions, and pure antioxidant peptides. Significant positive effects have been observed in many assays using peptides from microalgea, invertebrates, and byproducts of the fishing industry, such as the milt, roe and viscera of fish. Even glycosylated fish has been shown to have positive results. The balance of gut microbiota populations significantly improves not only in healthy mice or rats, but also in unhealthy ones subject to fatigue, alcohol-induced injury, and high-fat diet (HFD). In addition, a peptide combined with calcium significantly increases the abundance of beneficial gut microbes, including Firmicutes and Lactobacillus, in low-calcium diet-fed rats. Calcium absorption also increased in these animals.

In a cross intervention study, 20 healthy subjects ate two diets with different protein sources. Non-seafood protein diet induced a decrease in the relative abundance of Clostridium cluster IV and increases in the Firmicutes / Bacteroidetes ratio and the microcapsule/bacteroidete ratio of Cunninghamia lanceolata. Compared to the diet of cod, pollack, saithe, and scallops, the diet of chicken, lean beef, turkey, pork, egg, milk and milk products is preferred by beneficial gut microbes. Further examination revealed that circulating triacylglycerol (TAG), total to high-density lipoprotein (HDL) cholesterol ratio, and circulating trimetlylamine oxide (TMAO) levels are each linked to specific intestinal microbes. The fish diet released high levels of TMAO into the circulatory system, and the composition and activity of gut microbiota is regulated by TMAO rather than by active peptides from fish muscle. This study showed that, in the human body, the role of a single antioxidant peptide on gut microbiota is difficult to disentangle from diet-wide effects, and that many factors must be considered during experiment design [68]. As mentioned above, the free radical scavenging activity of peptides from fish viscera and cartilage exhibit higher activity than those from fish muscle. Peptides from other underused fish tissues may play significant roles in the regulation of gut microbiota for anti-aging purposes. Drosophila melanogaster is a useful model for studying the interactions between non-pathogenic microbes and the host because it can be genetically and experimentally manipulated [105]. In addition, it can provide an integrative approach to study the relationships between active compounds 
and the gut microbiome. However, no reports on the impacts of marine peptides on the microbiome of Drosophila melanogaster were found.

\section{Conclusions and Perspectives}

This review provides a comprehensive overview of the antiaging activities of marine peptides from underused resources, including the head, bone, skin, cartilage, viscera and gelatin of various fishes, several kinds of microalgae, mussels, rotifers and Trapa japonica. The potential antiaging activities of natural peptides from underused marine organisms have been investigated in vitro, in cells, in animal models and in human clinical trials. These peptides act using the following molecular mechanisms: free radical scavenging, enhancing oxidase activity, protecting mitochondria, downregulating the apoptotic pathway, inhibiting MMP-1 expression, and restoring intestinal homeostasis. These results suggest that underused marine peptides have great potential as functional food and cosmetic ingredients for antiaging purposes. However, presently, there are three major outstanding issues. First, relevant research reports in the Web of Science database are few, and not enough animal assays have reported. We therefore focused on in vitro assays for this review. Second, in the limited literature, very few marine species have been explored, and vast marine protein resources are still underutilized. Third, apart from several applications in skin aging, there is a dearth of information about marine peptides in human clinical trials related to antiaging. This lack of literature makes it difficult to apply and transform these peptides for the market. To address these issues, further exploration of the abundant underused marine peptide sources is required.

Author Contributions: Conceptualization, E.X., H.G. and J.N.; Funding acquisition, J.N. and H.G.; Project administration, H.G., E.X.; Writing-original draft, E.X., X.Z. and X.G.; Writing-review and editing, H.G., J.N. All authors have read and agreed to the published version of the manuscript.

Funding: This study was funded by grants from Discipline construction project of Guangdong Medical University (4SG21016G and 4SG21001G), Scientific research foundation of Guangdong Medical University (2XK20037), Scientific research innovation project for college students of Guangdong Medical University (2KY17018) and grant from Dongguan Key Laboratory of Environmental Medicine.

Institutional Review Board Statement: Not applicable.

Conflicts of Interest: The authors declare no conflict of interest.

\section{References}

1. Mitchell, S.J.; Scheibye-Knudsen, M.; Longo, D.L.; de Cabo, R. Animal models of aging research: Implications for human aging and age-related diseases. Annu. Rev. Anim. Biosci. 2015, 3, 283-303. [CrossRef]

2. Xia, E.; Zhu, S.; He, M.; Luo, F.; Fu, C.; Zou, T. Marine peptides as potential agents for the management of Type 2 Diabetes Mellitus-A prospect. Mar. Drugs 2017, 15, 88. [CrossRef]

3. Podhorecka, M.; Ibanez, B.; Dmoszyńska, A. Metformin-Its potential anti-cancer and anti-aging effects. Postep. Hig. Med. Dosw. (Online) 2017, 71, 170-175. [CrossRef]

4. Harman, D. Aging: A theory based on free radical and radiation chemistry. J. Gerontol. 1956, 11, 298-300. [CrossRef]

5. Lara, J.; Sherratt, M.J.; Rees, M. Aging and anti-aging. Maturitas 2016, 93, 1-3. [CrossRef]

6. Son, D.H.; Park, W.J.; Lee, Y.J. Recent advances in anti-aging medicine. Korean J. Fam. Med. 2019, 40, 289-296. [CrossRef]

7. Jin, Q.; Peng, D.; Zheng, Z. Advances in extracting and understanding the bioactivities of marine organism peptides: A review. J. Food Process Pres. 2021, e15602. [CrossRef]

8. Dhaval, A.; Yadav, N.; Purwar, S. Potential applications of food derived bioactive peptides in management of health. Int. J. Pept. Res. Ther. 2016, 22, 377-398. [CrossRef]

9. Beltrán-Barrientos, L.M.; García, H.S.; Torres-Llanez, M.J.; González-Córdova, A.F.; Hernández-Mendoza, A.; Vallejo-Cordoba, B. Safety of milk-derived bioactive peptides. Int. J. Dairy Technol. 2017, 70, 16-22. [CrossRef]

10. Schaafsma, G. Safety of protein hydrolysates, fractions thereof and bioactive peptides in human nutrition. Eur. J. Clin. Nutr. 2009, 63, 1161. [CrossRef]

11. Clemente, A. Enzymatic protein hydrolysates in human nutrition. Trends Food Sci. Technol. 2000, 11, 254-262. [CrossRef]

12. Chai, M.; Ye, Y.; Chen, V. Separation and concentration of milk proteins with a submerged membrane vibrational system. $J$. Membr. Sci. 2017, 524, 305-314. [CrossRef] 
13. Jo, C.; Khan, F.F.; Khan, M.I.; Iqbal, J. Marine bioactive peptides: Types, structures, and physiological functions. Food Rev. Int. 2017, 33, 44-61. [CrossRef]

14. Edgar, S.; Hopley, B.; Genovese, L.; Sibilla, S.; Laight, D.; Shute, J. Effects of collagen-derived bioactive peptides and natural antioxidant compounds on proliferation and matrix protein synthesis by cultured normal human dermal fibroblasts. Sci. Rep. 2018, 8, 10474. [CrossRef] [PubMed]

15. Ito, N.; Seki, S.; Ueda, F. Effects of composite supplement containing collagen peptide and ornithine on skin conditions and plasma IGF-1 levels-A randomized, double-blind, placebo-controlled trial. Mar. Drugs 2018, 16, 482. [CrossRef]

16. Zhou, T.; Wang, N.; Xue, Y.; Ding, T.; Liu, X.; Mo, X.; Sun, J. Development of Biomimetic Tilapia collagen nanofibers for skin regeneration through inducing keratinocytes differentiation and collagen synthesis of dermal fibroblasts. ACS Appl. Mater. Inter. 2015, 7, 3253-3262. [CrossRef] [PubMed]

17. Lima, T.N.; Moraes, C.A.P. Bioactive peptides: Applications and relevance for cosmeceuticals. Cosmetics 2018, 5, 21. [CrossRef]

18. Aguilar-Toalá, J.E.; Hernández-Mendoza, A.A.; González-Córdov, F.; Vallejo-Cordob, B.A.; Liceaga, M. Potential role of natural bioactive peptides for development of cosmeceutical skin products. Peptides 2019, 122, 170170. [CrossRef] [PubMed]

19. Venkatesan, J.; Anil, S.; Kim, S.K.; Shim, M.S. Marine fish proteins and peptides for cosmeceuticals: A review. Mar. Drugs 2017, 15, 143. [CrossRef]

20. Schulz, I.; Mahler, H.C.; Boiteux, S.; Epe, B. Oxidative DNA base damage induced by singlet oxygen and photosensitization: Recognition by repair endonucleases and mutagenicity. Mutat. Res. 2000, 461, 145-156. [CrossRef]

21. Chi, C.; Cao, Z.; Wang, B.; Hu, F.; Li, Z.; Zhang, B. Antioxidant and functional properties of collagen hydrolysates from Spanish mackerel skin as influenced by average molecular weight. Molecules 2014, 19, 11211-11230. [CrossRef] [PubMed]

22. Castro, I.A.; Rogero, M.M.; Junqueira, R.M.; Carrapeiro, M.M. 2,2-Diphenyl-1-picrylhydrazil free radical scavenging activity of antioxidant mixtures evaluated by response surface methodology. Int. J. Food Sci. Technol. 2006, 41, 59-67. [CrossRef]

23. Pan, X.; Wang, Y.; Li, L.; Chi, C.; Wang, B. Four antioxidant peptides from protein hydrolysate of red stingray (Dasyatis akajei) cartilages: Isolation, identification, and activity evaluation. Mar. Drugs 2019, 17, 263. [CrossRef]

24. Nazeer, R.A.; Kumar, N.S.S. Purification and identification of antioxidant peptide from black pomfret, Parastromateus niger (Bloch, 1975) viscera protein hydrolysate. Food Sci. Biotechnol. 2011, 20, 1087-1094.

25. Zhang, Y.; Jiang, W.; Hao, X.; Tan, J.; Wang, W.; Yu, M.; Zhang, G.; Zhang, Y. Preparation of the Enzymatic hydrolysates from Chlorella vulgaris protein and assessment of their antioxidant potential using Caenorhabditis elegans. Mol. Biotechnol. 2021, 1-9. [CrossRef]

26. Heo, S.Y.; Ko, S.C.; Kim, C.S.; Oh, G.W.; Ryu, B.; Qian, Z.J.; Kim, G.; Park, W.S.; Choi, I.W.; Phan, T.T.; et al. A heptameric peptide purified from Spirulina sp. gastrointestinal hydrolysate inhibits angiotensin I-converting enzyme- and angiotensin II-induced vascular dysfunction in human endothelial cells. Int. J. Mol. Med. 2017, 39, 1072-1082. [CrossRef]

27. Xia, E.; Zhai, L.; Huang, Z.; Liang, H.; Yang, H.; Song, G.; Li, W.; Tang, H. Optimization and identification of antioxidant peptide from underutilized Dunaliella salina protein: Extraction, gastrointestinal digestion, and fractionation. BioMed Res. Int. 2019, 2019, 6424651. [CrossRef] [PubMed]

28. Matsuo, H.; Mokudai, T.; Higo, M.; Nonaka, K.; Nagano, Y.; Nagahama, T.; Niwano, Y.; Takahashi, Y.; Omura, S.; Nakashima, T. Cipralphelin, a new anti-oxidative N-cinnamoyl tripeptide produced by the deep sea-derived fungal strain Penicillium brevicompactum FKJ-0123. J. Antibiot. 2019, 72, 775-778. [CrossRef]

29. Tripathi, V.C.; Horam, S.; Singh, A.; Lata, M.; Reddy, T.J.; Arockiaraj, J.; Pasupuleti, M. The discovery of antioxidants in marine microorganisms and their protective effects on the hepatic cells from chemical-induced oxidative stress. Free Rad. Res. 2020, 54, 150-161. [CrossRef] [PubMed]

30. Zhang, S.; Han, L.; Shi, Y.; Li, X.; Zhang, X.; Hou, H.; Lin, H.; Liu, K. Two Novel multi-functional peptides from meat and visceral mass of marine snail neptunea arthritica cumingii and their activities. Mar. Drugs 2018, 16, 473. [CrossRef]

31. Yang, X.; Qiu, Y.; Zhao, Y.; Chi, C.; Wang, B. Purification and characterization of antioxidant peptides derived from protein hydrolysate of the marine bivalve mollusk Tergillarca granosa. Mar. Drugs 2019, 17, 251. [CrossRef] [PubMed]

32. Byun, H.-G.; Lee, J.K.; Park, H.G.; Jeon, J.-K.; Kim, S.-K. Antioxidant peptides isolated from the marine rotifer, Brachionus rotundiformis. Process Biochem. 2009, 44, 842-846. [CrossRef]

33. Zhao, G.; Yang, X.; Wang, Y.; Zhao, Y.; Chi, C.; Wang, B. Antioxidant peptides from the protein hydrolysate of Spanish Mackerel (Scomberomorous niphonius) muscle by gastrointestinal digestion and their activities. Mar. Drugs 2019, 17, 531. [CrossRef]

34. Zhang, J.; Zhao, Y.; Wang, Y.; Chi, C.; Wang, B. Eight collagen peptides from hydrolysate fraction of Spanish Mackerel skins: Isolation, identification, and antioxidant activity evaluation. Mar. Drugs 2019, 17, 224. [CrossRef]

35. Zhang, L.; Zhao, G.; Zhao, Y.; Qiu, Y.; Chi, C.; Wang, B. Identification and active evaluation of antioxidant peptides from protein hydrolysates of skipjack tuna (Katsuwonus pelamis) head. Antioxidants 2019, 8, 318. [CrossRef] [PubMed]

36. Neves, A.C.; Harnedy, P.A.; O'Keeffe, M.B.; Alashi, M.A.; Aluko, R.E.; FitzGerald, R.J. Peptide identification in a salmon gelatin hydrolysate with antihypertensive, dipeptidyl peptidase IV inhibitory and antioxidant activities. Food Res. Int. 2017, 100, 112-120. [CrossRef]

37. Himaya, S.W.A.; Ngo, D.-H.; Ryu, B.; Kim, S.-K. An active peptide purified from gastrointestinal enzyme hydrolysate of Pacific cod skin gelatin attenuates angiotensin-1 converting enzyme (ACE) activity and cellular oxidative stress. Food Chem. 2012, 132, 1872-1882. [CrossRef] 
38. Mendis, E.; Rajapakse, N.; Byun, H.G.; Kim, S.K. Investigation of jumbo squid (Dosidicus gigas) skin gelatin peptides for their in vitro antioxidant effects. Life Sci. 2005, 77, 2166-2178. [CrossRef]

39. Abdelhedi, O.; Jridi, M.; Jemil, I.; Mora, L.; Toldrá, F.; Aristoy, M.-C.; Boualga, A.; Nasri, M.; Nasri, R. Combined biocatalytic conversion of smooth hound viscera: Protein hydrolysates elaboration and assessment of their an-tioxidant, anti-ACE and antibacterial activities. Food Res. Int. 2016, 86, 9-23. [CrossRef]

40. Kim, S.Y.; Je, J.Y.; Kim, S.K. Purification and characterization of antioxidant peptide from hoki (Johnius belenge-rii) frame protein by gastrointestinal digestion. J. Nutr. Biochem. 2007, 18, 31-38. [CrossRef] [PubMed]

41. Jun, S.Y.; Park, P.J.; Jung, W.K.; Kim, S.K. Purification and characterization of an antioxidative peptide from enzymatic hydrolysate of yellowfin sole (Limanda aspera) frame protein. Eur. Food Res. Technol. 2004, 219, 20-26.

42. Je, J.-Y.; Qian, Z.-J.; Byun, H.-G.; Kim, S.-K. Purification and characterization of an antioxidant peptide obtaine-d from tuna backbone protein by enzymatic hydrolysis. Process Biochem. 2007, 42, 840-846. [CrossRef]

43. Je, J.-Y.; Park, P.-J.; Kim, S.-K. Antioxidant activity of a peptide isolated from Alaska pollack (Theragra chalcogramma) frame protein hydrolysate. Food Res. Int. 2005, 38, 45-50. [CrossRef]

44. Liu, Z.; Ren, Z.; Zhang, J.; Chuang, C.C.; Kandaswamy, E.; Zhou, T.; Zuo, L. Role of ROS and nutritional antioxidants in human diseases. Front. Physiol. 2018, 9, 477. [CrossRef]

45. Oh, Y.; Ahn, C.B.; Nam, K.H.; Kim, Y.K.; Yoon, N.Y.; Je, J.Y. Amino acid composition, antioxidant, and cytoprotective effect of blue mussel (Mytilus edulis) hydrolysate through the inhibition of caspase-3 activation in oxidative stress-mediated endothelial cell injury. Mar. Drugs 2019, 17, 135. [CrossRef]

46. Saji, N.; Francis, N.; Blanchard, C.L.; Schwarz, L.J.; Santhakumar, A.B. Rice bran phenolic compounds regulate genes associated with antioxidant and anti-inflammatory activity in human umbilical vein endothelial cells with induced oxidative stress. Int. J. Mol. Sci. 2019, 20, 4715. [CrossRef]

47. Oh, Y.; Ahn, C.B.; Je, J.Y. Cytoprotective role of edible seahorse (Hippocampus abdominalis)-derived peptides in $\mathrm{H}_{2} \mathrm{O}_{2}$-induced oxidative stress in human umbilical vein endothelial cells. Mar. Drugs 2021, 19, 86. [CrossRef]

48. Redza-Dutordoir, M.; Averill-Bates, D.A. Activation of apoptosis signalling pathways by reactive oxygen species. BBA Mol. Cell Res. 2016, 1863, 2977-2992. [CrossRef]

49. Kang, K.; Qian, Z.; Ryu, B.; Karadeniz, F.; Kim, D.; Kim, S.K. Antioxidant peptides from protein hydrolysate of microalgae Navicula incerta and their protective effects in HepG2/CYP2E1 cells induced by ethanol. Phytother. Res. PTR 2012, 26, 1555-1563. [CrossRef]

50. Fisher, G.J.; Kang, S.; Varani, J.; Bata-Csorgo, Z.; Wan, Y.; Datta, S.; Voorhees, J.J. Mechanisms of photoaging and chronological skin aging. Arch. Dermatol. 2002, 138, 1462-1470. [CrossRef]

51. Lin, P.; Hua, N.; Hsu, Y.C.; Kan, K.W.; Chen, J.H.; Lin, Y.H.; Lin, Y.H.; Kuan, C.M. Oral Collagen Drink for Antiaging: Antioxidation, facilitation of the increase of collagen synthesis, and improvement of protein folding and DNA repair in human skin fibroblasts. Oxid. Med. Cell. Longev. 2020, 2020, 8031795. [CrossRef]

52. Han, J.; Huang, Z.; Tang, S.; Lu, C.; Wan, H.; Zhou, J.; Li, Y.; Ming, T.; Jim Wang, Z.; Su, X. The novel peptides ICRD and LCGEC screened from tuna roe show antioxidative activity via Keap1/Nrf2-ARE pathway regulation and gut microbiota modulation. Food Chem. 2020, 327, 127094. [CrossRef]

53. Jang, J.; Kim, M.; Nam, G.-H.; Kang, S.; Lee, K.-Y.; Park, Y.-J. Antiaging activity of peptide identified from fermented Trapa Japonica fruit extract in human dermal fibroblasts. Evid.-Based Compl. Alt. Med. 2020, 2020, 1-8. [CrossRef] [PubMed]

54. Pittayapruek, L.; Häkkinen, V.; Uitto, J.; Larjava, H. Cell biology of gingival wound healing. Periodontology 2000, 24, 127-152.

55. Zou, Y.; Liu, Y.; Ruan, M.; Feng, X.; Wang, J.; Chu, Z.; Zhang, Z. Cordyceps sinensis oral liquid prolongs the lifespan of the fruit fly, Drosophila melanogaster, by inhibiting oxidative stress. Int. Mol. Med. 2015, 36, 939-946. [CrossRef]

56. Gutierrez, E.; Wiggins, D.; Fielding, B.; Gould, A.P. Specialized hepatocyte-like cells regulate Drosophila lipid metabolism. Nature 2007, 445, 275-280. [CrossRef] [PubMed]

57. Chen, Y.; Liu, X.; Wu, L.; Tong, A.; Zhao, L.; Liu, B.; Zhao, C. Physicochemical characterization of polysaccharides from Chlorella pyrenoidosa and its anti-ageing effects in Drosophila melanogaster. Carbohyd. Polym. 2018, 185, 120-126. [CrossRef]

58. Rehman, S.U.; Shah, S.A.; Ali, T.; Chung, J.I.; Kim, M.O. Anthocyanins reversed D-Galactose-induced oxidative stress and neuroinflammation mediated cognitive impairment in adult rats. Mol. Neurobiol. 2017, 54, 255-271. [CrossRef] [PubMed]

59. Lin, L.; Zhu, Q.; Zheng, L.; Zhao, M.; Fan, J.; Liu, S. Preparation of sea cucumber (Stichopus variegates) peptide fraction with desired organoleptic property and its anti-aging activity in fruit flies and D-galactose-induced aging mice. J. Func. Foods 2020, 69, 103954. [CrossRef]

60. Sonani, R.R.; Singh, N.K.; Awasthi, A.; Prasad, B.; Kumar, J.; Madamwar, D. Phycoerythrin extends life span and health span of Caenorhabditis elegans. Age 2014, 36, 9717. [CrossRef]

61. Yu, X.; Su, Q.; Shen, T.; Chen, Q.; Wang, Y.; Jia, W. Antioxidant peptides from sepia esculenta hydrolyzate attenuate oxidative stress and fat accumulation in Caenorhabditis elegans. Mar. Drugs 2020, 18, 490. [CrossRef]

62. Jia, W.; Peng, Q.; Su, L.; Yu, X.; Ma, C.; Liang, M.; Yin, X.; Zou, Y.; Huang, Z. Novel bioactive peptides from Meretrix meretrix protect Caenorhabditis elegans against free radical-induced oxidative stress through the stress response factor DAF-16/FOXO. Mar. Drugs 2018, 16, 444. [CrossRef]

63. Wang, K.; Chen, S.; Zhang, C.; Huang, J.; Wu, J.; Zhou, H.; Jin, L.; Qian, X.; Jin, J.; Lyu, J. Enhanced ROS production leads to excessive fat accumulation through DAF-16 in Caenorhabditis elegans. Exp. Gerontol. 2018, 112, 20-29. [CrossRef] [PubMed] 
64. Wang, Y.; Gagnon, J.; Nair, S.; Sha, S. Herring milt protein hydrolysate improves iInsulin resistance in high-fat-diet-induced obese male C57BL/6J mice. Mar. Drugs 2019, 17, 456. [CrossRef]

65. Ferrucci, L.; Guralnik, J.M.; Pahor, M.; Corti, M.C.; Havlik, R.J. Hospital diagnoses, Medicare charges, and nursing home admissions in the year when older persons become severely disabled. JAMA 1997, 277, 728-734. [CrossRef]

66. Stineman, M.G.; Xie, D.; Pan, Q.; Kurichi, J.E.; Saliba, D.; Streim, J. Activity of daily living staging, chronic health conditions, and perceived lack of home accessibility features for elderly people living in the community. J. Am. Geriatr. Soc. 2011, 59, 454-462. [CrossRef]

67. Zhou, Y.; Xu, Q.; Dong, Y.; Zhu, S.; Song, S.; Sun, S. Supplementation of mussel peptides reduces aging phenotype, lipid deposition and oxidative stress in D-Galactose-induce aging mice. J. Nutr. Health Aging 2017, 21, 1314-1320. [CrossRef] [PubMed]

68. Schmedes, M.; Brejnrod, A.D.; Aadland, E.K.; Kiilerich, P.; Kristiansen, K.; Jacques, H.; Lavigne, C.; Graff, I.E.; Eng, Ø.; Holthe, A.; et al. The effect of lean-seafood and non-seafood diets on fecal metabolites and gut microbiome: Results from a randomized crossover intervention study. Mol. Nutr. Food Res. 2019, 63, e1700976. [CrossRef] [PubMed]

69. Han, S.B.; Won, B.; Yang, S.C.; Kim, D.H. Asterias pectinifera derived collagen peptide-encapsulating elastic nanoliposomes for the cosmetic application. J. Ind. Eng. Chem. 2021, 98, 289-297. [CrossRef]

70. DeBacker, C.M.; Putterman, A.M.; Zhou, L.; Holck, D.E.E.; Dutton, J.J. Age-related changes in type-I collagen synthesis in human eyelid skin. Ophthal. Plast. Recons. Surg. 1998, 14, 13-16. [CrossRef]

71. Sibilla, S.; Godfrey, M.; Brewer, S.; Budh-Raja, A.; Genovese, L. An overview of the beneficial effects of hydrolysed collagen as a nutraceutical on skin properties: Scientific background and clinical studies. Open Nutraceut. J. 2015, 8, 29-42. [CrossRef]

72. Fan, J.; Zhuang, Y.; Li, B. Effects of collagen and collagen hydrolysate from jellyfish umbrella on histological and immunity changes of mice photoaging. Nutrients 2013, 5, 223-233. [CrossRef]

73. Rubiolo, J.A.; Mithieux, G.; Vega, F.V. Resveratrol protects primary rat hepatocytes against oxidative stress damage: Activation of the Nrf2 transcription factor and augmented activities of antioxidant enzymes. Eur. J. Pharmacol. 2008, 591, 66-72. [CrossRef]

74. Cai, S.; Wang, Y.; Zhao, Y.; Chi, C.; Wang, B. Cytoprotective effect of antioxidant pentapeptides from the protein hydrolysate of Swim bladders of Miiuy Croaker (Miichthys miiuy) against $\mathrm{H}(2) \mathrm{O}(2)$-mediated human umbilical vein endothelial cell (HUVEC) injury. Int. J. Mol. Sci. 2019, 20, 5425. [CrossRef]

75. Kuro, O.M. The Klotho proteins in health and disease. Nat. Rev. Nephrol. 2019, 15, 27-44. [CrossRef]

76. Quarles, L.D. Fibroblast growth factor 23 and $\alpha$-Klotho co-dependent and independent functions. Curr. Opin. Nephrol. Hypertens. 2019, 28, 16-25. [CrossRef]

77. Richter, B.; Faul, C. FGF23 Actions on Target Tissues-With and Without Klotho. Front. Endocrinol. 2018, 9, 189. [CrossRef] [PubMed]

78. Li, S.; Yu, L.; He, A.; Liu, Q. Klotho inhibits unilateral ureteral obstruction-induced endothelial-to-mesenchymal transition via TGF- $\beta 1 /$ Smad2/Snail1 signaling in Mice. Front. Pharmacol. 2019, 10, 348. [CrossRef] [PubMed]

79. Iurciuc, S.; Cimpean, A.M.; Mitu, F.; Heredea, R.; Iurciuc, M. Vascular aging and subclinical atherosclerosis: Why such a "never ending" and challenging story in cardiology? Clin. Interv. Aging 2017, 12, 1339-1345. [CrossRef]

80. Oh, S.W.; Mukhopadhyay, A.; Dixit, B.L.; Raha, T.; Green, M.R.; Tissenbaum, H.A. Identification of direct DAF-16 targets controlling longevity, metabolism and diapause by chromatin immunoprecipitation. Nat. Genet. 2006, 38, $251-257$.

81. Li, W.; Shi, Y.; Chang, C.; Huang, C.; Hsiu-Chuan Liao, V. Selenite protects Caenorhabditis elegans from oxidative stress via DAF-16 and TRXR-1. Mol. Nutr. Food Res. 2014, 58, 863-874. [CrossRef]

82. Zhao, S.; Cheng, Q.; Peng, Q.; Yu, X.; Yin, X.; Liang, M.; Ma, C.; Huang, Z.; Jia, W. Antioxidant peptides derived from the hydrolyzate of purple sea urchin (Strongylocentrotus nudus) gonad alleviate oxidative stress in Caenorhabditis elegans. J. Func. Foods 2018, 48, 594-604. [CrossRef]

83. Thannickal, V.J.; Fanburg, B.L. Reactive oxygen species in cell signaling. Am. J. Physiol. Lung Cell Mol. Physiol. 2000, 279, 1005-1028. [CrossRef]

84. Karbowski, M.; Kurono, C.; Wozniak, M.; Ostrowski, M.; Teranishi, M.; Nishizawa, Y.; Usukura, J.; Soji, T.; Wakabayashi, T. Free radical-induced megamitochondria formation and apoptosis. Free Radic. Bio. Med. 1999, 26, 396-409. [CrossRef]

85. Klaunig, J.; Wang, Z.; Pu, X.; Zhou, S. Oxidative stress and oxidative damage in chemical carcinogenesis. Toxicol. Appl. Pharmacol. 2011, 254, 86-99. [CrossRef]

86. Burns, T.F.; El-Deiry, W.S. The p53 pathway and apoptosis. J. Cell. Physiol. 1999, 181, 231-239. [CrossRef]

87. Di Marzo, N.; Chisci, E.; Giovannoni, R. The role of hydrogen peroxide in redox-dependent signaling: Homeostatic and pathological responses in mammalian cells. Cells 2018, 7, 156. [CrossRef]

88. Yang, X.; Song, W.; Liu, N.; Sun, Z.; Liu, R.; Liu, Q.; Zhou, Q.; Jiang, G. Synthetic phenolic antioxidants cause perturbation in Steroidogenesis and. Environ. Sci. Technol. 2018, 52, 850-858. [CrossRef]

89. Feldman, M.E.; Apsel, B.; Uotila, A.; Loewith, R.; Knight, Z.A.; Ruggero, D.; Shokat, K.M. Active-site inhibitors of mTOR target rapamycin-resistant outputs of mTORC1 and mTORC2. PLoS Biol. 2009, 7, e38. [CrossRef]

90. Ekim, B.; Magnuson, B.; Acosta-Jaquez, H.A.; Keller, J.A.; Feener, E.P.; Fingar, D.C. mTOR kinase domain phosphorylation promotes mTORC1 signaling, cell growth, and cell cycle progression. Mol. Cell. Biol. 2011, 31, 2787-2801. [CrossRef]

91. Martin, R.; Desponds, C.; Eren, R.O.; Quadroni, M.; Thome, M.; Fasel, N. Caspase-mediated cleavage of raptor participates in the inactivation of mTORC1 during cell death. Cell Death Discov. 2016, 2, 16024. [CrossRef] [PubMed] 
92. Nam, G.H.; Jo, K.J.; Park, Y.S.; Kawk, H.W.; Yoo, J.G.; Jang, J.D.; Kang, S.M.; Kim, S.Y.; Kim, Y.M. Bacillus/Trapa japonica fruit extract ferment filtrate enhances human hair follicle dermal papilla cell proliferation via the Akt/ERK/GSK-3 $\beta$ signaling pathway. BMC Complement Altern. Med. 2019, 19, 104. [CrossRef] [PubMed]

93. Schaide, T.; Cabrera-Bañegil, M.; Pérez-Nevado, F.; Esperilla, A.; Martín-Vertedor, D. Effect of olive leaf extract combined with Saccharomyces cerevisiae in the fermentation process of table olives. J. Food Sci. Technol. 2019, 56, 3001-3013. [CrossRef]

94. Prost-Squarcioni, C.; Fraitag, S.; Heller, M.; Boehm, N. Functional histology of dermis. Ann. Dermatol. Venereol. 2008, 135, 5-20. [CrossRef]

95. Bornstein, P.; Sage, H. Regulation of collagen gene expression. Prog. Nucleic Acid Res. Mol. Biol. 1989, 37, 67-106.

96. Kähäri, V.-M.; Saarialho-Kere, U. Matrix metalloproteinases in skin. Exp. Dermatol. 1997, 6, 199-213. [CrossRef]

97. Cui, N.; Hu, M.; Khalil, R.A. Biochemical and biological attributes of matrix metalloproteinases. Prog. Mol. Biol. Transl. Sci. 2017, $147,1-73$.

98. Egeblad, M.; Werb, Z. New functions for the matrix metalloproteinases in cancer progression. Nat. Rev. Cancer 2002, 2, 161-174. [CrossRef]

99. Papaluca, A.; Wagner, J.R.; Saragovi, H.U.; Ramotar, D. UNG-1 and APN-1 are the major enzymes to efficiently repair 5hydroxymethyluracil DNA lesions in C. elegans. Sci. Rep. 2018, 8, 6860.

100. Komakula, S.S.B.; Tumova, J.; Kumaraswamy, D.; Burchat, N.; Vartanian, V.; Ye, H.; Dobrzyn, A.; Lloyd, R.S.; Sampath, H. The DNA repair protein OGG1 protects against obesity by altering Mitochondrial Energetics in white adipose tissue. Sci. Rep. 2018, 8, 14886. [CrossRef]

101. Nong, V.H.; Arahira, M.; Phan, V.C.; Kim, C.S.; Zhang, D.Y.; Udaka, K.; Fukazawa, C. Molecular cloning and characterization of a group II chaperonin delta-subunit from soybean. J. Biochem. 2002, 132, 291-300. [CrossRef]

102. Pussila, M.; Toronen, P.; Einarsdottir, E.; Katayama, S.; Krjutskov, K.; Holm, L.; Kere, J.; Peltomaki, P.; Makinen, M.J.; Linden, J.; et al. Mlh1 deficiency in normal mouse colon mucosa associates with chromosomally unstable colon cancer. Carcinogenesis 2018, 39, 788-797. [CrossRef]

103. O'Toole, P.W.; Jeffery, I.B. Gut microbiota and aging. Science 2015, 350, 1214-1215. [CrossRef] [PubMed]

104. Rakoff-Nahoum, S.; Paglino, J.; Eslami-Varzaneh, F.; Edberg, S.; Medzhitov, R. Recognition of commensal microflora by toll-like receptors is required for intestinal homeostasis. Cell 2004, 118, 229-241. [CrossRef]

105. Labachyan, K.E.; Kiani, D.; Sevrioukov, E.A.; Schriner, S.E.; Jafari, M. The impact of Rhodiola rosea on the gut microbial community of Drosophila melanogaster. Gut Pathog. 2018, 10, 12. [CrossRef]

106. Chandler, J.A.; Lang, J.M.; Bhatnagar, S.; Eisen, J.A.; Kopp, A. Bacterial communities of diverse Drosophila species: Ecological context of a host-microbe model system. PLoS Genet. 2011, 7, e1002272. [CrossRef]

107. Kallus, S.J.; Brandt, L.J. The intestinal microbiota and obesity. J. Clin. Gastroenterol. 2012, 46, 16-24. [CrossRef]

108. De Bandt, J.P.; Waligora-Dupriet, A.J.; Butel, M.J. Intestinal microbiota in inflammation and insulin resistance: Re-levance to humans. Curr. Opin Clin. Nutr. Metab. Care 2011, 14, 334-340. [CrossRef]

109. Claesson, M.J.; Jeffery, I.B.; Conde, S.; Power, S.E.; O’Connor, E.M.; Cusack, S.; Harris, H.M.; Coakley, M.; Lakshminarayanan, B.; O'Sullivan, O.; et al. Gut microbiota composition correlates with diet and health in the elderly. Nature 2012, 488, 178-184. [CrossRef] [PubMed]

110. Borrelli, A.; Bonelli, P.; Tuccillo, F.M.; Goldfine, I.D.; Evans, J.L.; Buonaguro, F.M.; Mancini, A. Role of gut microbiota and oxidative stress in the progression of non-alcoholic fatty liver disease to hepatocarcinoma: Current and innovative therapeutic approaches. Redox. Biol. 2018, 15, 467-479. [CrossRef]

111. Zhang, J.; Zhao, X.; Jiang, Y.; Zhao, W.; Guo, T.; Cao, Y.; Teng, J.; Hao, X.; Zhao, J.; Yang, Z. Antioxidant status and gut microbiota change in an aging mouse model as influenced by exopolysaccharide produced by Lactobacillus plantarum YW11 isolated from Tibetan kefir. J. Dairy Sci. 2017, 100, 6025-6041. [CrossRef]

112. Lee, J.; Hwang, K.T.; Chung, M.Y.; Cho, D.H.; Park, C.S. Resistance of Lactobacillus casei KCTC 3260 to reactive oxygen species (ROS): Role for a metal ion chelating effect. J. Food Sci. 2005, 70, 388-M391. [CrossRef]

113. Li, W.; Lu, L.; Liu, B.; Qin, S. Effects of phycocyanin on pulmonary and gut microbiota in a radiation-induced pulmonary fibrosis model. Biomed. Pharmacother. 2020, 132, 110826. [CrossRef]

114. Han, K.; Jin, W.; Mao, Z.; Dong, S.; Zhang, Q.; Yang, Y.; Chen, B.; Wu, H.; Zeng, M. Microbiome and butyrate production are altered in the gut of rats fed a glycated fish protein diet. J. Func. Foods 2018, 47, 423-433. [CrossRef]

115. Wang, S.; Lv, Z.; Zhao, W.; Wang, L.; He, N. Collagen peptide from Walleye pollock skin attenuated obesity and modulated gut microbiota in high-fat diet-fed mice. J. Func. Foods 2020, 74, 04194. [CrossRef]

116. Mei, F.; Duan, Z.; Chen, M.; Lu, J.; Zhao, M.; Li, L.; Shen, X.; Xia, G.; Chen, S. Effect of a high-collagen peptide diet on the gut microbiota and short-chain fatty acid metabolism. J. Func. Foods 2020, 75, 104278. [CrossRef]

117. Durand, R.; Ouellette, A.; Houde, V.P.; Guénard, F.; Varin, T.V.; Marcotte, B.; Pilon, G.; Fraboulet, E.; Vohl, M.C.; Marette, A.; et al Animal and cellular studies demonstrate some of the beneficial impacts of herring milt hydrolysates on obesity-induced glucose intolerance and inflammation. Nutrients 2020, 12, 3235. [CrossRef]

118. Wu, J.; Qiao, K.; Lu, H.; Chen, X.; Su, J.; Liu, Z. Abalone viscera protein hydrolysate modulation of gut microbiota in a mouse model of alcohol induced injury. J. Aquat. Food Prod. Technol. 2017, 26, 880-889. [CrossRef]

119. Hua, P.; Yu, Z.; Xiong, Y.; Liu, B.; Zhao, L. Regulatory efficacy of Spirulina platensis protease hydrolyzate on lipid metabolism and gut microbiota in high-fat diet-fed rats. Int. Mol. Sci. 2018, 19, 4023. [CrossRef] 
120. Hua, P.; Xiong, Y.; Yu, Z.; Liu, B.; Zhao, L. Effect of Chlorella pyrenoidosa protein hydrolysate-calcium chelate on calcium absorption metabolism and gut microbiota composition in low-calcium diet-fed rats. Mar. Drugs 2019, 17, 6. [CrossRef] [PubMed]

121. Xiao, M.; Lin, L.; Chen, H.; Ge, X.; Huang, Y.; Zheng, Z.; Li, S.; Zeng, F. Anti-fatigue property of the oyster polypeptide fraction and its effect on gut microbiota in mice. Food Func. 2020, 11, 8659-8669. [CrossRef] [PubMed] 